\title{
What drives DS30 Index amid bourse lockdown decision? An emerging economy perspective.
}

\author{
Mohammad Omar Faruq \\ Department of Accounting and Information Systems, \\ Faculty of Business Studies, \\ Comilla University, Cumilla-3506
}

\begin{abstract}
This study measures the impact of the COVID-19 pandemic outbreak on the stock market of Bangladesh amid bourse lockdowns. The top 30 blue-chip companies listed in the DS30 Index of the Dhaka Stock Exchange are used as the sample for this study. Panel data regression analysis has been used after performing several diagnostics tests to assess the impact for January to December during the year 2020. The regression model used in the study considers three key aspects, namely COVID-19, firm-specific factors, and macroeconomic variables amid the bourse lockdown. This study finds that daily trends in affected cases, death cases and investors' attention significantly affect the stock market but does not show any negative relation to conclude. The Government imposed lockdown shows a negative relation with the stock market significantly. Firm-specific variables like daily market capitalization and book to market ratio show a significant negative relationship with the stock market. On the other hand, macroeconomic factors have a significantly positive impact on the stock market amid bourse lockdowns. This study assesses the performance of the Bangladesh stock market by use of DS30 Index listed firms during the COVID-19 pandemic in response to the Government imposed bourse lockdown. This study provides unique insights into how the Bangladesh stock market reacted during the pandemic, along with a rare bourse lockdown decision.
\end{abstract}

Keywords: DS30 INDEX, COVID-19, MACROECONOMIC FACTORS, LOCKDOWN, INVESTOR'S ATTENTION

Type of article: Research Paper

JEL Classification: G01, G15, G18, I18

\section{Introduction}

Bangladesh is considered one of the rising economic performers in South Asia. Macroeconomic indicators and other global indicators suggest that the presence of economic development have encouraged investors for trading in the stock market. The stock market is under constant regulation and proper governance while considering the uninterrupted focus of the authority in the protection of investors' interests. Two stock exchanges facilitate stock trading for the investors in the country. Dhaka Stock Exchange (DSE) is the largest exchange, along with the Chittagong Stock Exchange (CSE) in Bangladesh (BSEC., 2020). All these stock exchanges have their price indices to reflect the activities in the market better. Lots of changes have occurred in the stock market and in the value of their indices since the outbreak. Investor's psychology in the economy of Bangladesh is already in a constant swing while it comes to the hold or sale decision in the long run. Government and regulators are always in fixed-term commitment to improving the market anyhow. Bangladesh Stock Exchange Commission (BSEC) took measures to set out the floor price of the share; earlier transactions began to take place. There has been a change in the administration and infrastructure of the DSE amid COVID-19 (TBS Report., 2020). In the contemporary scenario, when the whole world is facing a global pandemic, it is quite challenging to keep up the stock market in every other aspect and, at the same time, work for the reduction in the number of deaths. As of June 1, 2021, the SARS-CoV-2 virus that is responsible for the COVID-19 disease has affected over 170.43 million people, with a death toll of 3.55 million around the globe (World Health Organization, 2021). 
This study tries to understand the specific causes behind the movement in the stock market during the COVID-19 pandemic. Bangladesh government-imposed lockdown to curtail the cases of infection due to the pandemic. In response to the nationwide decision of lockdown, the stock market regulator also ordered a shutdown in trading while other stock markets were still trading in the region. This study looks for the answers to two specific questions. Firstly, what causes movement in the stock return during a pandemic? And secondly, how can the market respond to the pandemic in the long run?

The stock market return depends on various policy implementation and regulation changes on a large scale. The introduction of stricter policy directives may influence the market in both a positive and negative manner. This study adds to the existing literature at least in three ways. First, it contributes to the findings of others regarding the impact of the pandemic on a country level (Anh \& Gan, 2020; He, Sun, Zhang \& Li, 2020; Huang, Zhuang \& Yao, 2009; Jelilov, Iorember, Usman \& Yua, 2020; Narayan, Devpura \& Wang, 2020; Panyagometh, 2020; Phan \& Narayan, 2020; Narayan, Devpura \& Wang, 2020; Waheed, Sarwar, Sarwar \& Khan, 2020). Secondly, it contributes to the study of others in the assessment of the impact of the COVID-19 on the stock market index during lockdown ( Aggarwal, Nawn \& Dugar, 2021; Al-Awadhi, Alsaifi, Al-Awadhi \& Alhammadi, 2020; Ashraf, 2020b; Baker, Bloom, Davis, Kost, Sammon \& Viratyosin, 2020; He, Liu, Wang \& Yu, 2020; Pavlyshenko, 2020; Ramelli \& Wagner, 2020; Topcu \& Gulal, 2020; Zhang, Hu \& Ji, 2020). Lastly, it complements findings of the previous studies relating to the impact of the firm-specific and macroeconomic factors on the stock market (Al-Awadhi et al., 2020; Almuqrin, 2020; Anh \& Gan, 2020; Au Yong \& Laing, 2021; Bahmani-Oskooee \& Saha, 2019; Baig, Butt, Haroon \& Rizvi, 2021; Bekiros, Shahzad, Arreola-Hernandez \& Ur Rehman, 2018; Bhusal, 2005; Boonyanam, 2014; Primiceri \& Tambalotti, 2020; Ullah, Hussain \& Rauf, 2014). Previous studies have assessed the impact of the pandemic by use of Pooled OLS regression method (Ashraf, 2020a, 2020b) and random effect models (Al-Awadhi et al., 2020). This study assesses the impact under the fixed effect panel data regression method like Anh \& Gan (2020) because it suited the cause after performing several panel diagnostic tests.

The remainder of the study is organized as follows. Under the "Overview and transition of Bangladesh Stock Market during the COVID-19 pandemic" narrative, the background information of the stock market before the pandemic appeared is described in a transitory manner. "Literature review and development of testable Hypothesis" chapter includes the previous studies and development of the hypothesis used in the study. "Data and Methodology" chapter details the selection of sample, data, and logic behind the development of the model. Empirical findings are described under the "Results and discussion" chapter. Finally, this paper concludes on the regulatory perspective, shortcomings, and orientations for future research precisely.

\subsection{Overview and transition of Bangladesh Stock Market during the COVID-19 pandemic:}

Historically the stock market was never halted from trading since its last discontinuation that occurred after the liberation war in 1971 up until the year 1976 (Hassan \& Chowdhury, 2008). Since then, the stock market in the country has gone through many broad phases of change to consider for improvement. During the financial crisis of Bangladesh that took place in the year 2010, the bullish market plunged into a bearish market amid artificial interference (Babu, 2020). In recent years before the occurrence of the COVID-19 pandemic, there was a presence of bearish movement in the stock market. Right after the general election of 2018, the market was still plunging into a bearish one while, in a broad sense, it was expected to be a bullish movement (Rahman, 2020). Under prevailing circumstances, it is seen that the stock market reacts positively to a stable political condition. Although there was a presence of several other explanations that validate the situation, there was indeed a desperate need for policy improvement to lift the market. Banking company scandals and liquidity crises all over the economy on the verge of the year 2019 led to a fall in the stock market at year-end. Several factors from the general business environment were held liable as usual for the disturbance in the market, along with vulnerabilities in the market regulations. Although there were several ups and downs to name, the trading continued without minor discrepancies till the lockdown was caused by COVID-19 (Corona Virus Disease-19).

Countrywide lockdown forced the Government to close daily trading in the stock market since March 25 of the year 2020. Such a halt in the stock market left investors in utter discomfort and with no other alternatives than to wait for further instructions. Closing the stock exchange as a response to a pandemic for such long days was merely seen in other countries to conclude. There was a remarkably massive technological transformation only after introducing the pandemic while referring to the previous significant technological 
transformation of automated trading facilities, which was introduced in the year 1998. The automated trading facilities started later in 2001, along with many other initiatives (Hassan \& Chowdhury, 2008).

Contemporary literature has pointed out that the cases and fatalities of the virus outbreak and proposed a relationship with the volatility in the stock market return (Ashraf, 2020b, 2020a; Cao, Li, Liu \& Woo, 2020; Liu, Manzoor, Wang, Zhang \& Manzoor, 2020; Pavlyshenko, 2020; Ramelli \& Wagner, 2020; Zeren \& Hizarci, 2020). Outcomes of the studies are mixed as some of these shows a positive while the other shows a negative relationship among these. This paper tries to investigate the impact of the stock movement in recent days due to the decision to shut down trading in the stock market. This is the first study to identify the impact of the COVID-19 pandemic along with the stock market lockdown decisions on DS30 index performance in DSE to the best knowledge of the author. The effect of the pandemic will be assessed with consideration of two timestamps, one being the before and another after the bourse lockdown. This study is expected to contribute to future research in the country by determining the effectiveness of the decision and providing a new aspect to the regulators of the stock market.

\section{Literature Review}

Historically there was no other pandemic outbreak that has affected the stock market significantly as like COVID-19. Baker et al. (2020) have found that government-imposed restrictions on various business activities and social distancing measures have influenced the market heavily than before. In their study, they have tried to quantify the impact of the news on disease outbreaks. Results of the study suggest that both negative and positive news relating to the COVID-19 outbreak drives the United States (U.S.) stock market. $\mathrm{He}$ et al. (2020) investigated empirically to identify the stock market performance in response to the COVID-19. He has found that specific industry responses were different from the other industries. The impact of the global virus outbreak has been well documented in many different industries to validate the arguments. Al-Awadhi et al. (2020) find that both cases and deaths caused by COVID-19 have a negative influence on the Chinese stock market return.

On the other hand, Ashraf (2020) have found that there was an inverse relationship between the return and cases. Alfaro, Chari, Greenland \& Schott (2020) and Zhang et al. (2020) have found that there were negative impacts of COVID-19 on the stock returns. Governments have imposed various restrictions and policies to tackle the adverse effect across the globe. Liu et al. (2020) tried to measure the short-term effect of the pandemic on some selected country's major indices. Results of the study suggest that the consequences of the pandemic on the stock market worldwide are on the negative side. Besides, countries in the Asian region have depicted an abnormal fall in stock returns. Anh and Gan (2020) have carried down a study to better understand the impact of COVID-19 on the Vietnam stock market during the nationwide lockdown in the country. VN-index (Vietnam market index) had faced a significant shock due to the COVID-19, which was evident earlier during the financial crisis of 2008 (Ginsberg, 2008). In the opinion of Van Hoof (2020), at least one-third of the people around the globe have experienced some lockdown amid the pandemic outbreak. Eleftheriou \& Patsoulis (2020) have found that there is a negative association between the COVID-19 and stock market performance. Baig et al. (2020) measured the effects of the pandemic on market performance during the lockdown and have understood that it was a negative one. Nationwide lockdown measures, social distancing, and policy implementation to tackle the adverse effect on the economy and the health of the citizens have left governments all over the world in a difficult scenario.

Smith (2006) described that the cost of SARS (severe acute respiratory syndrome) back in 2003 was around 30 to 100 billion in USD. During 2003, severe acute respiratory syndrome (SARS) was estimated to cost the world between 30-100 billion USD (Smith, 2006). Zhang et al. (2020) suggest that the impact on the economy of the world due to the pandemic will be a profound one. Lyócsa, Baumohl, Výrost and Molnár (2020) concluded that societies had been affected negatively, and the world has lost so much within a shorter period. Authors have also found that the search trend for COVID-19 related word which reflects fear has a significant positive association with the stock prices.

Topcu and Gulal (2020) describe that due to the sluggish movement of the economic progress and shortage of capital flows, emerging markets around the globe will suffer more. Huo and Qiu (2020) conducted a study to identify the reaction of China's stock market in response to the COVID-19 lockdown. In the study paper, the authors have explained that as of the infectious nature of the pandemic, there has been a presence of aggressive policies by governments all over the world. Baker et al. (2020) suggest that social distancing has an impact on economic activity as the restrictions imposed by government authorities. Also, the service 
sectors in an economy face the most difficulties in response to the social distancing as there is a need for such activities extensively.

BSEC being the country's leading stock market regulator, tries to introduce newer toolsets to improve the market conditions. The nationwide lockdown has also led to the shutdown of the stock market since March 25, which was observant in the DSE trading from the next days. After the introduction of the lockdown, the fear of foreign investors has raised in respect of the local share market condition. Some of the foreign investment experts have suggested that the prolonged shutdown of the stock market may see a negative review in the MSCI index (Morgan Stanley Capital International) for the coming days (Rahman, 2020). MSCI Bangladesh index is such a measure that aids in assessing the performance of the market on a global scale while taking account of $85 \%$ of the equity market.

\subsection{Development of testable Hypotheses}

Contemporary researches show a significant negative impact of COVID-19 on the stock market performance (Anh \& Gan, 2020; Ashraf, 2020b, 2020a). Variables used in such studies include growth in the number of affected cases and growth in the number of death cases. This study assumes another COVID-19 related variable which is the trend in investors' attention. This variable is already being used in other studies under different names (Baig et al., 2021; Iyke \& Ho, 2021). Following the previous findings, this study assumes a negative relationship between COVID-19 and stock return.

\section{H1: COVID-19 has a significant negative impact on the stock market during pandemic lockdown}

Bourse lockdown decision curtails the operational integrity of the stock market. While the other bourse market was trading in the region, Bangladesh decided to go on a complete shutdown. What benefits such a decision brought needs to be quantified. Anh \& Gan (2020) and Sun, Wu, Zeng \& Peng (2021) also assessed such impact and found that the government-imposed lockdown has a negative impact on the stock market. Lockdown decisions by the Government create fear among the investors as it creates uncertainty about the market growth. This study also assumes a negative relationship between lockdown and stock market return.

\section{H2: Government imposed lockdown has a significant negative relationship with the stock market}

Empirical findings suggest that firm-specific characteristics such as market capitalization have a negative impact on the stock market return during pandemic lockdown (Al-Awadhi et al., 2020). Daily market capitalization is a widely accepted indicator for assessing the worth of a company at any given time. Anh \& Gan (2020) and $\mathrm{Au}$ Yong \& Laing (2021) found that market capitalization has a significant and negative impact on the stock market return. Baig et al. (2021) also found a similar result, but they have assessed the impact on the volatility index. Kheradyar, Ibrahim and Nor (2011) observed that the book to market ratio has higher predictive power than all other financial ratios. Cordeiro da Cunha Araújo \& André Veras Machado (2018) observed a significant positive impact of the book to market ratio on the stock market return in all the models they have used. In this study, we assume the opposite, which is that the book to market ratio has a significant negative relationship with the stock market as we are considering the time of pandemic lockdown. Such assumption is valid as while choosing to use the book to market ratio as a predictor, the consideration of the environment is an important factor (Wang \& Xu, 2004).

\section{H3: Firm-specific characteristics have a significant negative impact on the stock market during pandemic lockdown}

(Bhusal, 2005) concluded that the consumer price index as a measure of inflation has a positive relationship with economic growth. (Boonyanam, 2014) also used the consumer price index as a measure for inflation and found a positive impact on the stock market return. Abdullah \& Hayworth (2013) and Ratanapakorn \& Sharma (2007) have found that inflation positively impacts the stock price. This study also assumes that there is a significant positive relationship between inflation and the stock market. Almuqrin (2020) considers industrial production as a representation of real economic activities and concluded that diverse government measures had affected the parameter differently during the pandemic. (Bahmani-Oskooee \& Saha, 2019) also included industrial production as a measure for real economic activities and stated that data for such an indicator is available to search for. Bekiros et al. (2018) and Primiceri \& Tambalotti (2020) use industrial production as a measure for macroeconomic indication. This study assumes a significant positive relationship between industrial production and the stock market.

H4: There is a significant positive relation between macroeconomic variables and the stock market 


\section{Methodology}

\subsection{Data}

This paper aims at measuring the impact of the COVID-19 pandemic amid the stock market lockdown on the daily DS30 stock market index. Here, the data of the daily stock exchange index ranges from January 5 2020 to December 30 2020. Data for the DS30 stock Index is collected from the website of the Dhaka Stock Exchange (https://www.dsebd.org/). The natural logarithm value of stock exchange indices is used by authors in numerous studies (Cao et al., 2020; Christ \& Bremmer, 2003; Hussain, 2014; Nasseh \& Strauss, 2000; Ullah et al., 2014). Dhaka Stock Exchange 30 (DS30) is one of the three major indices maintained by the Dhaka Stock Exchange (DSE). DS30 Index reflects around 51\% of the equity market capitalization and is an investable index. In addition, DS30 listed companies are blue-chip companies in the market. DSE (Dhaka Stock Exchange) rebalances the indices regularly in alignment with the free-float methodology designed by Standards and Poor's Dow Jones Indices (S\&P). Companies are listed in the Index only if they have a float-adjusted market capitalization which is much higher in comparison with other indices in the market. DS30 Index is rebalanced semi-annually and considered as stable indices available in the market (Dey \& Faruq, 2019). The selection of such an index can be justified from the ground of ensuring the inclusion of the total representative equity market. Also, DS30 relates closely to the other two indices of DSE in terms of design and excludes debentures, bonds, and mutual funds. Companies listed in a stock exchange react at a different scale to prevalent differences in the change in regulation and volatility of the economy. This study needs such a sample selection that will represent a stable and less volatile equity market and diverse industry at the same time to demonstrate the impact of specific changing conditions. From every aspect of our study, DS30 suits our needs effectively.

Data regarding the COVID-19 are collected from the John Hopkins University (JHU) datasets for affected cases and death cases. Recent COVID-19 related studies included the affected and death cases to measure for the pandemic Farzanegan, Gholipour, Feizi, Nunkoo and Andargoli, 2021; Sharif, Aloui \& Yarovaya, 2020). The number of COVID-19 affected cases are shown in Figure 1 and the highest number of infections recorded during the year is 4,019 during the month of July.

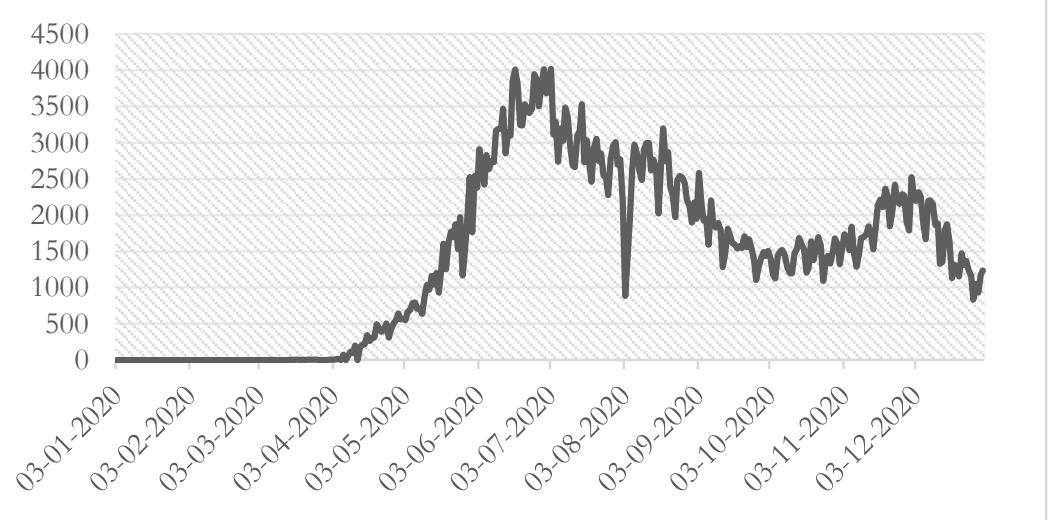

Figure 1. Number of Affected Cases

Figure 2 shows the number of death cases during the year. The highest number of recorded death cases was 64 during the month of July. Data of COVID-19 supports the fact that the pandemic hits the country during the middle of the year mostly, and the impact gradually slowed down later.

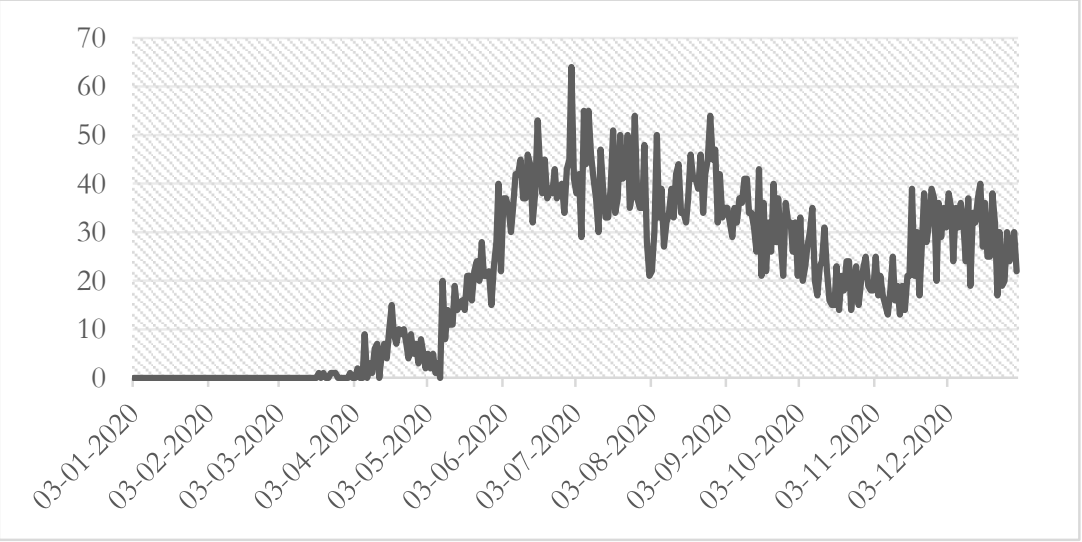

Figure 2. Number of Death Cases 
This study collects the data for investor attention through the use of the Google Trends websites (https://trends.google.com/trends/) data. Google trend is used to generate data regarding the popularity of a specific search time over a specific period in a specific location. The index values range from 0 to 100 and can be used to define the data required for the investor attention variable. This study followed the process of Iyke and Ho (2021), where the authors have searched for the keywords, which are Coronavirus, COVID-19, COVID, COVID19 and COVID 19. Figure1 displays the Index of each of the search terms used in Bangladesh during the period of the study. During the pandemic, the most searched term related to COVID19 was Coronavirus. Other studies also used similar indexes to measure trends regarding Coronavirus search terms (Baig et al., 2021). This study uses the daily growth in the Coronavirus search term index to measure the value of DTIA $_{t-1}$.

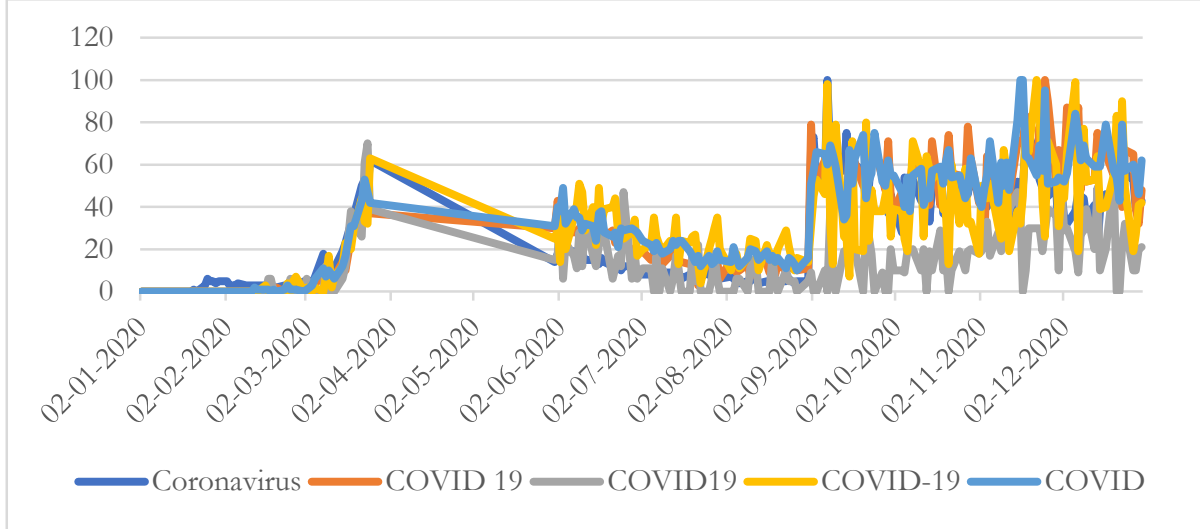

Figure 3. Trends in COVID-19-related Google searches

(The sample is from January 22020 to December 31 2020.)

This study uses two firm-specific which are $\mathrm{LNMCAP}_{i, t}$ (Market Capitalization) and $\mathrm{BTM}_{i, t}$ (Book to Market ratio). Data for these two variables are collected from the financial web portal of LankaBangla (https://lankabd.com/). LankaBangla financial porter provides with live update of the Dhaka Stock Exchange. This study uses these two variables to represent the firm-specific factors after reviewing several pieces of literature to ensure effective representation (Al-Awadhi et al., 2020; Anh \& Gan, 2020; Au Yong \& Laing, 2021; Baig et al., 2021).

The macroeconomic impact of the pandemic is also assessed in this study by use of two variables after reviewing previous related studies to ensure the inclusiveness of such indicators. $\mathrm{LNCPI}_{t}$ is used in various studies as a representative macroeconomic indicator for inflation (Bahmani-Oskooee \& Saha, 2019; Bhusal, 2005; Boonyanam, 2014; Hussain, 2014; Primiceri \& Tambalotti, 2020; Ullah et al., 2014). LNCPI ${ }_{t}$ is the natural logarithm of the monthly data of the Consumer Price Index. LNQIIP ${ }_{t}$ is the natural logarithm of monthly data of Quantum Index of Industrial Production. Industrial Production Index is used in diverse fields of study as a representative variable for macroeconomic indicator (Almuqrin, 2020; BahmaniOskooee \& Saha, 2019; Bekiros et al., 2018; Primiceri \& Tambalotti, 2020). Data regarding these two macroeconomic variables are available from the publications of BBS (Bangladesh Bureau of Statistics).

L.E. $t$ is a dummy variable which equals to 1 if the day is before March 26, 2020; 0 otherwise to represent the impact of stock market lockdown. Lockdown is measured as a dummy variable in other studies regarding COVID-19 (Anh \& Gan, 2020; Sun et al., 2021). Lockdown is measured with a binary value of 0 and 1 in the study of Anh \& Gan (2020), who have found a significant negative correlation between lockdown efforts and market return. Sun et al. (2021) also found that mandatory lockdown shows a negative impact on both liquidity and volatility of the market.

\subsection{Methodology}

This study measures the impact of the COVID-19 pandemic on the stock market of Bangladesh by executing a panel data regression for the period of January 2020 to December 2020. There are several benefits of using panel data. Firstly, it facilitates the use of several control variables which are supposedly not observable or measurable that variables that are time-variant, not on the basis of entity (Mughal et al., 2021). Secondly, panel data regression considers the cross-sectional and time-varying aspects and reduces the bias of heteroskedasticity and multicollinearity (Anh \& Gan, 2020; Wooldridge, 2010). Other than this, COVID-19 is not a single-time event, and it evolves over a matter of days in a country (Ashraf, 2020b). This study follows the model of (Al-Awadhi et al., 2020; Anh \& Gan, 2020; Ashraf, 2020b) to measure the influence of the daily rise in COVID-19 incidents on Bangladesh's stock market returns. The following panel data 
regression model is constructed to assess the relationship between the DS30 Index and several independent variables.

$\operatorname{LNDS} 30_{\mathrm{t}}=\gamma_{0}+$

$\gamma_{1}$ COVID-19 ${ }_{\mathrm{t}-1}+\gamma_{2}$ L.E.t $_{\cdot t}+\gamma_{3}$ LNMCAP $_{\mathrm{i}, \mathrm{t}}+\gamma_{4}$ BTM $_{\mathrm{i}, \mathrm{t}}+\gamma_{5}$ LNCPI $_{\mathrm{t}}+\gamma_{6}$ LNQIIP $_{\mathrm{t}}+\sum$ Day effect dummies $+\varepsilon_{\mathrm{t}}$

Here, $i$ denotes the individual firm listed in the DS30 Index and $t$ refers to the day during the pandemic that ranges from the month of January to December. COVID-19 denotes (1) the daily trend in affected cases (DTAC), (2) the daily trend in death cases (DTDC) and (3) the daily trend in investor attention (DTIA). (L.E.) is our main variable of interest which indicates the timestamp of the bourse lockdown. There are two firm-specific variables that include the natural logarithm of daily market capitalization (LNMCAP) and the value of the book-to-market ratio of the individual firm (BTM). In addition, there are two macroeconomic variables that are also used in this study, which are the natural logarithm of a consumer price index (LNCPI) and the natural logarithm of the quantum index of industrial production (LNQIIP). "Day effect dummies" is used in this study to effectively control for systematic risk present in the industry. $\varepsilon_{\mathrm{t}}$ is the error term for the model.

Detailed definitions of the variables that are used in the model and their intended measure are tabulated in the operational definition of variables Table 1. Before conducting panel data analysis, this study checked for Levin-Lin-Chu unit roots and found that all the variables are stationary, which is an essential parameter for progressing further. After checking for unit root tests, we have executed panel model diagnostics methods to choose between Pooled OLS, Fixed effect and Random effect model by using Gretl econometric software package. Results from the F-statistics and Hausman test is in favour of the fixed-effects model. This study uses robust standard errors clustered by firm that is believed to be heteroskedasticity-autocorrelationconsistent for determining the statistical significance of coefficient estimates.

Table 1. Operational definition of Variables

\begin{tabular}{|c|c|c|}
\hline Variables & Measure & Operational definition \\
\hline LNDS30 & Dhaka Stock Exchange 30 & Natural logarithm of daily DS30 Index at day $t$. \\
\hline DTAC & $\begin{array}{l}\text { Daily Trend in Affected } \\
\text { Cases }\end{array}$ & $\begin{array}{l}\text { Growth in the daily number of COVID-19 } \\
\text { infection cases at day } t \text {. }\end{array}$ \\
\hline DTDC & $\begin{array}{l}\text { Daily Trend in Death } \\
\text { Cases }\end{array}$ & $\begin{array}{l}\text { Growth in the daily number of COVID-19 death } \\
\text { cases at day } t \text {. }\end{array}$ \\
\hline DTIA & $\begin{array}{l}\text { Daily Trend in Investors' } \\
\text { Attention }\end{array}$ & $\begin{array}{l}\text { Growth in the daily search term in Google trend } \\
\text { index for the keyword: Coronavirus at day } t \text {. }\end{array}$ \\
\hline LNMCAP & Market Capitalization & $\begin{array}{l}\text { Natural logarithm of daily market capitalization } \\
\text { of firm } i \text { on day } t \text {. }\end{array}$ \\
\hline BTM & Book to Market ratio & (Book value/Market value) of firm $i$ on day $t$. \\
\hline LNCPI & Consumer Price Index & $\begin{array}{l}\text { Natural logarithm of the monthly data of } \\
\text { Consumer Price Index }\end{array}$ \\
\hline LNQIIP & $\begin{array}{l}\text { Quantum Index } \\
\text { Industrial Production }\end{array}$ & $\begin{array}{l}\text { Natural logarithm of the monthly data of } \\
\text { Quantum Index of Industrial Production. }\end{array}$ \\
\hline L.E. & Lockdown effect & $\begin{array}{l}\text { Equals } 1 \text { if the day is before March 26, 2020; } 0 \\
\text { otherwise. }\end{array}$ \\
\hline
\end{tabular}

Notes: Sources of data are discussed in the section labelled: Data

\section{Empirical Analysis}

During the government-imposed lockdown, there was a complete shutdown of trading in the countries two stock markets. These two bourses remained closed from March 26 to May 31. Later, during the bourse lockdown, there was an appointment of a new director to the countries stock exchange regulator (BSEC) after completion of the previous one. The value of all three major indices maintained by the DSE plummeted down a while after the lockdown; there seems to be a positive comeback, as can be observed from Figure 4. Such a movement in the stock market demands a closer look in depth. 


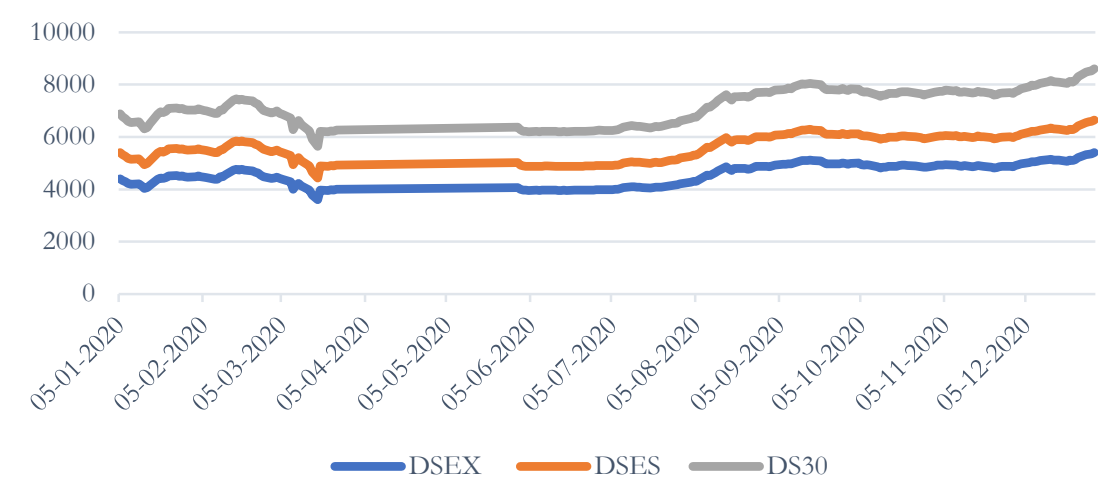

Figure 4. Comparative daily index value of Dhaka Stock Exchange

\subsection{Descriptive statistics}

Table 1 displays the detailed result of summary statistics of the variables used in this study. The mean and standard deviation of LNDS30 is (7.348) and (.109). LNDS30 is the natural logarithm value of the daily DS30 Index. The mean value of LNDS30 implies that the average value of the Index over the time period is (1561.62). DTAC and DTDC have a mean value of (.01) and (.054) while the standard deviation is (.19) and (.272). The mean value of DTAC shows that there is a 10 per cent daily growth in affected cases, while the DTDC show that there is only a 5.4 per cent growth rate in daily death cases. DTIA reports a mean value of (.097) along with a standard deviation of (.938). The mean value suggests that there is a 9 per cent daily growth rate in the search term for Coronavirus. LNMCAP is one of the firm-specific variables used in the study, with a mean value of (24.104) and a standard deviation of (1.054). Such a value of standard deviation suggests that there is a significant spread in the daily market capitalization. Another company-specific variable, BTM, which measure the book-to-market ratio, has a mean, and standard deviation of (.948) and (.845), also shows that there is a significant deviation in the security valuation. The average value of the BTM ratio suggests the presence of a higher number of overvalued companies which in term implies that the investors believe in the companies listed in the DS30 Index for future growth. Such future growths can be observed as the investor's faith in these blue-chip companies in terms of future profitability and project viability in the long run.

Table 2. Descriptive Statistics

\begin{tabular}{|l|c|c|c|c|c|}
\hline Variable & Obs. & Mean & Std. Dev. & Min & Max \\
\hline LNDS30 & 6180 & 7.348 & .109 & 7.093 & 7.583 \\
\hline DTAC & 6180 & .01 & .19 & -1 & 1 \\
\hline DTDC & 6180 & .054 & .272 & -1 & .897 \\
\hline DTIA & 6180 & .097 & .938 & -1 & 12.8 \\
\hline LNMCAP & 6180 & 24.104 & 1.054 & 22.573 & 27.19 \\
\hline BTM & 6180 & .948 & .845 & .053 & 6.334 \\
\hline LNCPI & 6180 & 5.644 & .024 & 5.611 & 5.682 \\
\hline LNQIIP & 6180 & 6.017 & .048 & 5.727 & 6.113 \\
\hline LE & 6180 & .718 & .45 & 0 & 1 \\
\hline
\end{tabular}

This study assesses the impact of macroeconomic factors by use of two variables. LNCPI, a reliable indicator of inflation, is the natural logarithm of monthly Consumer Price Index value, which has a mean and standard deviation of (5.644) and (.024). The average value of CPI over the period of study was 282.80. Another macroeconomic indicator, LNQIIP, represents the natural logarithm of the monthly value of the Quantum Index of Industrial Production, which is also known as the Industrial Production Index (IPI). The mean and standard deviation of LNQIIP is (6.017) and (.048), where the average value of QIIP is 410. Lastly, L.E., a dummy for lockdown effect, has a mean and standard deviation value of (.718) and (.45), respectively.

\subsection{Spearman's correlations}

Table 2 shows the results of Spearman correlations between the explanatory variables used in this study. The results show a significant relationship between LNDS30 and all the independent variables at a 5\% level of significance.

Table 3. Spearman's correlations 


\begin{tabular}{|c|c|c|c|c|c|c|c|c|c|}
\hline Variables & LNDS30 & DTAC & DTDC & DTIA & LNMCAP & BTM & LNCPI & LNQIIP & LE \\
\hline LNDS30 & 1.000 & & & & & & & & \\
\hline DTAC & $\begin{array}{c}-0.040^{*} \\
(0.0018)\end{array}$ & 1.000 & & & & & & & \\
\hline DTDC & $\begin{array}{c}0.100 * \\
(0.0000) \\
\end{array}$ & $\begin{array}{c}0.036^{*} \\
(0.0051) \\
\end{array}$ & 1.000 & & & & & & \\
\hline DTIA & $\begin{array}{c}-0.036^{*} \\
(0.0044) \\
\end{array}$ & $\begin{array}{c}-0.078^{*} \\
(0.0000) \\
\end{array}$ & $\begin{array}{c}0.048^{*} \\
(0.0002) \\
\end{array}$ & 1.000 & & & & & \\
\hline LNMCAP & $\begin{array}{c}0.095 * \\
(0.0000)\end{array}$ & $\begin{array}{c}-0.005 \\
(0.7033)\end{array}$ & $\begin{array}{c}0.013 \\
(0.3107)\end{array}$ & $\begin{array}{c}0.002 \\
(0.8704)\end{array}$ & 1.000 & & & & \\
\hline BTM & $\begin{array}{l}-0.119 * \\
(0.0000)\end{array}$ & $\begin{array}{c}0.003 \\
(0.7874)\end{array}$ & $\begin{array}{c}-0.013 \\
(0.2952)\end{array}$ & $\begin{array}{c}0.004 \\
(0.7281)\end{array}$ & $\begin{array}{c}-0.353 * \\
(0.0000)\end{array}$ & 1.000 & & & \\
\hline LNCPI & $\begin{array}{c}0.639^{*} \\
(0.0000) \\
\end{array}$ & $\begin{array}{c}-0.011 \\
(0.4071) \\
\end{array}$ & $\begin{array}{c}0.093^{*} \\
(0.0000) \\
\end{array}$ & $\begin{array}{c}-0.036^{*} \\
(0.0049) \\
\end{array}$ & $\begin{array}{c}0.096^{*} \\
(0.0000) \\
\end{array}$ & $\begin{array}{c}-0.077^{*} \\
(0.0000) \\
\end{array}$ & 1.000 & & \\
\hline LNQIIP & $\begin{array}{c}0.368^{*} \\
(0.0000) \\
\end{array}$ & $\begin{array}{c}-0.017 \\
(0.1699) \\
\end{array}$ & $\begin{array}{c}0.042 * \\
(0.0009) \\
\end{array}$ & $\begin{array}{c}-0.019 \\
(0.1348) \\
\end{array}$ & $\begin{array}{c}0.025^{*} \\
(0.0455) \\
\end{array}$ & $\begin{array}{c}-0.050^{*} \\
(0.0001) \\
\end{array}$ & $\begin{array}{c}0.450^{*} \\
(0.0000) \\
\end{array}$ & 1.000 & \\
\hline LE & $\begin{array}{c}0.353^{*} \\
(0.0000) \\
\end{array}$ & $\begin{array}{c}0.037 * \\
(0.0038) \\
\end{array}$ & $\begin{array}{c}0.124^{*} \\
(0.0000)\end{array}$ & $\begin{array}{l}-0.070^{*} \\
(0.0000) \\
\end{array}$ & $\begin{array}{c}0.022 \\
(0.0816) \\
\end{array}$ & $\begin{array}{c}-0.035^{*} \\
(0.0058) \\
\end{array}$ & $\begin{array}{c}0.263^{*} \\
(0.0000) \\
\end{array}$ & $\begin{array}{l}-0.179 * \\
(0.0000) \\
\end{array}$ & 1.000 \\
\hline
\end{tabular}

The maximum pairwise correlation of (0.63) between LNCPI and LNDS30 and (-0.353) between BTM and LNMCAP suggests that there is no problem of multicollinearity in the regression model. In addition to Spearman correlation, this study also measures the VIF (Variance Inflationary Factor) for the explanatory variables to check for any problem of multicollinearity. The result of the VIF ranges from 1.01 to 1.18 with a mean VIF of 1.10, which falls below the threshold of 5. With the reassurance of the results of the VIF tests, this study can finally conclude that there is no existence of multicollinearity among the explanatory variables.

\subsection{Regression analysis}

Table 3 shows the output of fixed effect panel data regression analysis through models (1), (2), (3) and (4) with consideration of robust standard errors clustered by firm. From the regression table, it is evident that growth in daily affected cases (DTAC) negatively affects the DS30 Index with a correlation coefficient and robust standard error value of (-0.007) and (0.007) in the model (1) and (-0.005) and (0.001) in the model (2). The findings of this study are similar to that of Al-Awadhi et al. (2020) and Ashraf (2020), who have also excluded the day effect dummies in his first two models. When the day fixed effect dummy is included, the scenario still remains significant, but the interpretation changes to be affecting the stock market positively with a coefficient and robust standard error of (0.019) and (0.004) in the model (3) and (0.012) and (0.001) in the model (4). This implies that the impact of infected cases is not of that much concern while investors are making trading decisions in the market. Another variable which is the daily trend in death cases (DTDC), remains positive and significant throughout the model (1), (2), (3) and (4), irrespective of the inclusion of the day effect dummy variable. This also suggests that investors are not that much invested in their decisions on the basis of death cases as it is an outcome of confirmed cases, and these occur several days later on of the cases of infection. Another COVID-19 related variable this study uses is the daily trend in investors' attention which also remains positively significant with a coefficient estimate of (0.006) in both models (1) and (2) while the estimate is (0.004) in both of the model (3) and (4). Another important variable which is the lockdown effect (L.E.), used as a measure to signify the event time impact, shows a significant negative impact on the stock index return when the day effect dummy is implied. This suggests that the market reacted negatively to the imposed bourse lockdown by the Government. This study uses two variables to represent firm-specific characteristics.

The natural logarithm of daily market capitalization (LNMCAP), being the first firm-specific variable, showed a negative impact on the stock index when the day fixed effect dummy is used with a robust standard error of (0.003) and coefficient estimate of (-0.001). This suggests that daily market capitalization in the market reacted negatively to the pandemic outbreak. Another important variable for firm-specific impact on the stock book to market ratio (BTM) market shows a significant negative impact on the stock market with a coefficient and robust standard error of (-0.091) and (0.047) for models (2) and (-0.06) and (0.032) for model (4). BTM measures whether the security is undervalued or overvalued. Such output of the variable implies that the stock market reacts significantly to the information whether the security is worthy or not. This is expected as such a piece of information provides the investors with the tendency to estimate whether the future growth and profitability of these DS30 blue-chip companies are viable or not. 
Table 4 Regression output

\begin{tabular}{|c|c|c|c|c|}
\hline & (1) & (2) & (3) & (4) \\
\hline & \multicolumn{4}{|c|}{ Natural Logarithm of Daily DS30 Index } \\
\hline \multirow[t]{2}{*}{ DTAC } & -.007 & $-.005 * * *$ & $.019 * * *$ & $.012 * * *$ \\
\hline & $(.007)$ & $(.001)$ & $(.004)$ & $(.001)$ \\
\hline \multirow[t]{2}{*}{ DTDC } & $.039 * * *$ & $.014 * * *$ & $.013 * * *$ & $.008 * * *$ \\
\hline & $(.005)$ & $(.001)$ & $(.003)$ & $(.001)$ \\
\hline \multirow[t]{2}{*}{ DTIA } & $.006^{* * *}$ & $.006 * * *$ & $.004 * * *$ & $.004 * * *$ \\
\hline & $(.001)$ & $(0)$ & $(.001)$ & $(0)$ \\
\hline \multirow[t]{2}{*}{ LE } & $.079 * * *$ & $.044 * * *$ & $-.242 * * *$ & $-.179 * * *$ \\
\hline & $(.003)$ & $(.008)$ & $(.004)$ & $(.004)$ \\
\hline \multirow[t]{2}{*}{ LNMCAP } & & .007 & & -.001 \\
\hline & & $(.018)$ & & $(.003)$ \\
\hline \multirow[t]{2}{*}{ BTM } & & $-.091 *$ & & $-.06 *$ \\
\hline & & $(.047)$ & & $(.032)$ \\
\hline \multirow[t]{2}{*}{ LNCPI } & & $2.256 * * *$ & & $.675 * * *$ \\
\hline & & $(.142)$ & & $(.054)$ \\
\hline \multirow[t]{2}{*}{ LNQIIP } & & $.459 * * *$ & & $.361 * * *$ \\
\hline & & $(.067)$ & & $(.047)$ \\
\hline \multirow[t]{2}{*}{ Constant } & $7.288 * * *$ & $-8.255 * * *$ & $-58.616 * * *$ & $-48.792 * * *$ \\
\hline & $(.002)$ & $(.653)$ & $(.637)$ & $(.921)$ \\
\hline Observations & 6180 & 6180 & 6180 & 6180 \\
\hline R-squared & .127 & .567 & .681 & .745 \\
\hline Day effect dummies? & $\mathrm{NO}$ & $\mathrm{NO}$ & YES & YES \\
\hline \multicolumn{5}{|c|}{$\begin{array}{l}\text { This table describes the fixed effect panel regression estimate of LNDS30 } \\
\text { stock index. The sample period ranges from January to December of the year } \\
2020 \text {. This study uses robust standard errors clustered by firms that are } \\
\text { heteroskedasticity autocorrelation-consistent to determine the statistical } \\
\text { significance of the coefficient estimates. } \\
\text { Robust standard errors are in parentheses } * * * p<.01 \text {, ** } p<.05, * p<.1\end{array}$} \\
\hline
\end{tabular}

The natural logarithm of the consumer price index (LNCPI), which is a measure of inflation, is used as one of the two macroeconomic determiners of the stock market performance. The result of the coefficient provides a significantly positive relationship with the DS30 index value with a coefficient and robust standard error of (2.256) and (0.142) in model (2), while in the model (4), the value is (0.675) and (0.054) respectively. This implies that an increase in the value of inflation increases the value of the stock market index. Another macroeconomic variable for the study is the natural logarithm value of the quantum index of industrial production (LNQIIP). This macroeconomic variable measures the contribution of various sectors to the economy. From the regression output table, it is evident that the variable is positively significant with a coefficient estimate and robust standard error of (0.459) and (0.067) in the model (2), while the day fixed effect dummy is not used. Although the use of the day fixed effect dummy does not demean the significance along with a value of (0.361) and (0.047) in the model (4). This result indicates that industrial performance is an important measure for assessing the performance of the stock market, which is a logical conclusion to make.

\section{Conclusion}

Research on the impact of COVID-19 on the Bangladesh stock market amid the bourse lockdown decision is a new one. This imposes several limitations of structuring a perfect model with variables that replicate the intended objective of the study. Several representative variables are tested against the impact of COVID-19 on the stock market in recent works of literature. This study filtered most of these variables as they failed to pass the fundamental diagnostic tests to be included in the regression model. Choosing between statistical significance and literary presence raises the cost of addition and deletion of a few interesting variables. Later, this study coined only these variables that are representative of the previous pieces of literature in the same field and simultaneously significant in the statistical periphery. After conducting a panel fixed effect regression analysis in consideration of heteroskedastic and autocorrelation problem findings suggests that COVID-19 related variables do not have a significant impact on the stock market during the pandemic. This is logical as the stock market was shut down during the surge of the pandemic. Later, after several 
precautionary measures had been taken, the stock market was opened again. Firm-specific variables have shown a significant negative impact on the stock market index. This is due to the unique natures of the bluechip firms in the market. Firms with different levels of worth and valuation affected the stock market differently. Macroeconomic variables, on the other hand, showed a positive impact on the stock market index. This suggests that the economy during the COVID-19 was contributing to the stock market return significantly. This is logical because the Government introduced several stimulus packages for the industry along with other aids to tackle the negative impact of the pandemic. This study also finds that the bourse lockdown imposed by the Government significantly affects the return of the stock market with strong significance.

The findings of the study are limited to several factors. Firstly, it failed to include several important variables that have been used in other similar research due to the problem of unit roots. Other than this, data regarding a few variables were not readily available at daily frequencies. This study includes a firm-day observation of 6,180, which is not enough to provide enough evidence for such a large stock market. Secondly, this research fails to include any primary data due to the lack of accessibility and communication as the country was in a strict lockdown. Other government action variables that have also been found to be significant in other studies can also be assessed with importance (Ashraf, 2020a). The event study method, although not used in this study, can provide extended insights into the current impact. Variables that represent the macroeconomic condition better can be introduced with statistical validity.

This paper is conducted to rapidly assess the Government's decision of bourse lockdown. Acknowledged and described findings in the study can be used as a unique insight into the market anomalies and disturbance. In future, the decision taker should also incorporate the fact that the mere pandemic lockdown does not improve the market condition. Stock market trading should never be halted down to reverse the consequences of a pandemic outbreak. Investors and creditors can support the production, distribution and research of vaccines and other emergency supplies during the lockdown if the market is still operational. In any stock market, there are companies directly involved in the production and distribution of medical supplies, which in turn requires investors positive attention. Stock markets should be organized and well prepared with precautionary measures to tackle any future pandemic. Future research in Bangladesh should include the government action level variables in their model to assess the scenario with more confidence.

\section{References}

1. Abdullah, D. A., \& Hayworth, S. C. (2013). University of Nebraska-Lincoln College of Business Administration Macroeconometrics of Stock Price Fluctuations. Journal of Business and Economics, 32(1), 50-67. http://www.jstor.org/stable/40473075

2. Aggarwal, S., Nawn, S., \& Dugar, A. (2021). What caused global stock market meltdown during the COVID pandemic-Lockdown stringency or investor panic? Finance Research Letters, 38, 101827. https://doi.org/10.1016/j.frl.2020.101827

3. Al-Awadhi, A. M., Alsaifi, K., Al-Awadhi, A., \& Alhammadi, S. (2020). Death and contagious infectious diseases: Impact of the COVID-19 virus on stock market returns. Journal of Behavioral and Experimental Finance, 27, 100326. https://doi.org/10.1016/j.jbef.2020.100326

4. Alfaro, L., Chari, A., Greenland, A. N., \& Schott, P. K. (2020). Aggregate and firm-level stock returns during pandemics, in real time (No. w26950). National Bureau of Economic Research.

5. Almuqrin, A. (2020). How is COVID-19 Related to the Global Economy? International Journal of Social Science and Human Research, 03(12), 437-448. https://doi.org/10.47191/ijsshr/v3-i12-11

6. Anh, D. L. T., \& Gan, C. (2020). The impact of the COVID-19 lockdown on stock market performance: evidence from Vietnam. Journal of Economic Studies. https://doi.org/10.1108/JES-06-2020-0312

7. Ashraf, B. N. (2020a). Economic impact of government interventions during the COVID-19 pandemic: International evidence from financial markets. Journal of Behavioral and Experimental Finance, 27, 100371. https://doi.org/10.1016/j.jbef.2020.100371

8. Ashraf, B. N. (2020b). Stock markets' reaction to COVID-19: Cases or fatalities? Research in International Business and Finance, 54, 101249. https://doi.org/10.1016/j.ribaf.2020.101249

9. Au Yong, H. H., \& Laing, E. (2021). Stock market reaction to COVID-19: Evidence from U.S. Firms' International exposure. International Review of Financial Analysis, 76(December 2020), 101656. https://doi.org/10.1016/j.irfa.2020.101656

10. Babu, M. U. (2020). Once there was a stock market. Retrieved September 11, 2020, from The 
Business Standard website: https://tbsnews.net/economy/stock/once-there-was-stock market84562.

11. Bahmani-Oskooee, M., \& Saha, S. (2019). On the effects of policy uncertainty on stock prices. Journal of Economics and Finance, 43(4), 764-778. https://doi.org/10.1007/s12197-019-09471-x

12. Baig, A. S., Butt, H. A., Haroon, O., \& Rizvi, S. A. R. (2021). Deaths, panic, lockdowns and U.S. equity markets: The case of COVID-19 pandemic. Finance Research Letters, 38(April). https://doi.org/10.1016/j.frl.2020.101701

13. Baker, S. R., Bloom, N., Davis, S. J., Kost, K., Sammon, M., \& Viratyosin, T. (2020). The Unprecedented Stock Market Reaction to COVID-19. The Review of Asset Pricing Studies, 19571958. https://doi.org/10.1093/rapstu/raaa008

14. Bekiros, S., Shahzad, S. J. H., Arreola-Hernandez, J., \& Ur Rehman, M. (2018). Directional predictability and time-varying spillovers between stock markets and economic cycles. Economic Modelling, 69(October 2017), 301-312. https://doi.org/10.1016/j.econmod.2017.10.003

15. Bhusal T.P., \& S. S. (2005). Inflation and Growth : Estimation of Threshold Point for. Economic Journal of Development Issues, 13(1), 1-15.

16. Boonyanam, N. (2014). Relationship of Stock Price and Monetary Variables of Asian Small Open Emerging Economy: Evidence from Thailand. International Journal of Financial Research, 5(1), 5263. https://doi.org/10.5430/ijfr.v5n1p52

17. BSEC. (2020). Stock exchanges. Retrieved September 12, 2020, from Bangladesh Securities and Exchanges Commission website: https://www.sec.gov.bd/home/stockex

18. Cao, K. H., Li, Q., Liu, Y., \& Woo, C. K. (2020). Covid-19's adverse effects on a stock market index. Applied Economics Letters, 00(00), 1-5. https://doi.org/10.1080/13504851.2020.1803481

19. Christ, K. P., \& Bremmer, D. S. (2003). The Relationship Between Consumer Sentiment and Stock Prices. October.

20. Cordeiro da Cunha Araújo, R., \& André Veras Machado, M. (2018). Book-to-Market Ratio, return on equity and Brazilian Stock Returns. RAUSP Management Journal, 53(3), 324-344. https://doi.org/10.1108/RAUSP-04-2018-001

21. Dey, P. K., \& Faruq, M. O. (2019). Determinants of Intellectual Capital Disclosure: An Investigation on DS30 Firms in Bangladesh. Asian Journal of Accounting Perspectives, 12(2), 27-48. https://doi.org/10.22452/ajap.vol12no2.2

22. Eleftheriou, K., \& Patsoulis, P. (2020). COVID-19 Lockdown Intensity and Stock Market Returns: A Spatial Econometrics Approach.

23. Farzanegan, M. R., Gholipour, H. F., Feizi, M., Nunkoo, R., \& Andargoli, A. E. (2021). International Tourism and Outbreak of Coronavirus (COVID-19): A Cross-Country Analysis. Journal of Travel Research, 60(3), 687-692. https://doi.org/10.1177/0047287520931593

24. Ginsberg, J. (2008). Vietnam's Economic Hiccups. Retrieved September 11, 2020, from Council on Foreign Relations website: https://www.cfr.org/backgrounder/vietnams-economic-hiccups

25. Hassan, M. K., \& Chowdhury, S. S. H. (2008). Efficiency of Bangladesh stock market: evidence from monthly Index and individual firm data. Applied Financial Economics, 18(9), 749-758.

26. He, P., Sun, Y., Zhang, Y., \& Li, T. (2020). COVID -19's Impact on Stock Prices Across Different Sectors-An Event Study Based on the Chinese Stock Market. Emerging Markets Finance and Trade, 56(10), 2198-2212. https://doi.org/10.1080/1540496X.2020.1785865

27. He, Q., Liu, J., Wang, S., \& Yu, J. (2020). The impact of COVID-19 on stock markets. Economic and Political Studies, 8(3), 275-288. https://doi.org/10.1080/20954816.2020.1757570

28. Huang, W. Q., Zhuang, X. T., \& Yao, S. (2009). A network analysis of the Chinese stock market. Physica A: Statistical Mechanics and Its Applications, 388(14), 2956-2964. https://doi.org/10.1016/j.physa.2009.03.028

29. Huo, X., \& Qiu, Z. (2020). How does China's stock market react to the announcement of the COVID19 pandemic lockdown?. Economic and Political Studies, 1-26.

30. Hussain, N. S. \& Z. (2014). STOCK PRICES IN PAKISTAN : The Case of Lahore Stock Exchange LongRun And Short-Run Relationship Between Macroeconomic Variables And Stock Prices In Pakistan. 47(2), 183-198. 
31. Iyke, B. N., \& Ho, S. Y. (2021). Investor attention on COVID-19 and African stock returns. MethodsX, 8, 101195. https://doi.org/10.1016/j.mex.2020.101195

32. Jelilov, G., lorember, P. T., Usman, O., \& Yua, P. M. (2020). Testing the nexus between stock market returns and inflation in Nigeria: Does the effect of COVID-19 pandemic matter? Journal of Public Affairs, 20(4). https://doi.org/10.1002/pa.2289

33. Kheradyar, S., Ibrahim, I., \& Nor, F. M. (2011). Stock Return Predictability with Financial Ratios. International Journal of Trade, Economics and Finance, 2(5), 391-396. https://doi.org/10.7763/ijtef.2011.v2.137

34. Liu, H., Manzoor, A., Wang, C., Zhang, L., \& Manzoor, Z. (2020). The COVID-19 outbreak and affected countries stock markets response. International Journal of Environmental Research and Public Health, 17(8), 1-19. https://doi.org/10.3390/ijerph17082800

35. Lyócsa, Š., Baumohl, E., Výrost, T., \& Molnár, P. (2020). Fear of the Coronavirus and the stock markets. Finance Research Letters, 101735.

36. Mughal, Y. H., Jehangir, M., Khan, M., \& Saeed, M. (2021). Nexus between corporate social responsibility and firm's performance: A panel data approach. International Journal of Finance and Economics, 26(2), 3173-3188. https://doi.org/10.1002/ijfe.1956

37. Narayan, P. K., Devpura, N., \& Wang, H. (2020). Japanese currency and stock market-What happened during the COVID-19 pandemic? Economic Analysis and Policy, 68, 191-198. https://doi.org/10.1016/j.eap.2020.09.014

38. Nasseh, A., \& Strauss, J. (2000). Stock prices and domestic and international macroeconomic activity: A cointegration approach. Quarterly Review of Economics and Finance, 40(2), 229-245. https://doi.org/10.1016/s1062-9769(99)00054-x

39. Panyagometh, K. (2020). The Effects of Pandemic Event on the Stock Exchange of Thailand. Economies, 8(4), 90. https://doi.org/10.3390/economies8040090

40. Pavlyshenko, B. M. (2020). Regression Approach for Modeling COVID-19 Spread and its Impact On Stock Market. 2020(1), 1-10. http://arxiv.org/abs/2004.01489

41. Phan, D. H. B., \& Narayan, P. K. (2020). Country Responses and the Reaction of the Stock Market to COVID-19-a Preliminary Exposition. Emerging Markets Finance and Trade, 56(10), 2138-2150. https://doi.org/10.1080/1540496X.2020.1784719

42. Primiceri, G. E., \& Tambalotti, A. (2020). Macroeconomic Forecasting in the Time of COVID-19. Working Paper, June.

43. Rahman, M. A. (2020). Covid-19 and the stock market of Bangladesh. Retrieved September 11, 2020, from The Business Standard website: https://www.tbsnews.net/thoughts/covid-19-andstock-market-bangladesh-90181

44. Ramelli, S., \& Wagner, A. (2020). Feverish Stock Price Reactions to COVID-19. The Review of Corporate Finance Studies. https://doi.org/10.1093/rcfs/cfaa012

45. Ratanapakorn, O., \& Sharma, S. C. (2007). Dynamic analysis between the U.S. stock returns and the macroeconomic variables. Applied Financial Economics, 17(5), 369-377. https://doi.org/10.1080/09603100600638944

46. Sharif, A., Aloui, C., \& Yarovaya, L. (2020). COVID-19 pandemic, oil prices, stock market, geopolitical risk and policy uncertainty nexus in the U.S. economy: Fresh evidence from the wavelet-based approach. International Review of Financial Analysis, 70(May), 101496. https://doi.org/10.1016/j.irfa.2020.101496

47. Smith, R. D. (2006). Responding to global infectious disease outbreaks: lessons from SARS on the role of risk perception, communication and management. Social science \& medicine, 63(12), 31133123.

48. Sun, Y., Wu, M., Zeng, X., \& Peng, Z. (2021). The impact of COVID-19 on the Chinese stock market: Sentimental or substantial? Finance Research Letters, 38, 101838. https://doi.org/10.1016/j.frl.2020.101838

49. TBS Report. (2020). Professor Shibli Rubayat new BSEC chairman. Retrieved September 11, 2020, from The Business Standard website: https://tbsnews.net/economy/stock/prof-shibli-rubayatappointed-bsec-chairman-82378. 
50. Topcu, M., \& Gulal, O. S. (2020). The impact of COVID-19 on emerging stock markets. Finance Research Letters, 101691. https://doi.org/10.1016/j.frl.2020.101691

51. Ullah, F., Hussain, I., \& Rauf, A. (2014). Impacts of Macroeconomy on Stock Market : Evidence From Pakistan. International Journal of Management and Sustainability, 3(3), 140-146. https://doi.org/10.18488/journal.11/2014.3.3/11.3.140.146

52. Van Hoof, E. (2020, April). Lockdown is the world's biggest psychological experiment-and we will pay the price. In World Economic Forum (Vol. 9).

53. Waheed, R., Sarwar, S., Sarwar, S., \& Khan, M. K. (2020). The impact of COVID-19 on Karachi stock exchange: Quantile-on-quantile approach using secondary and predicted data. Journal of Public Affairs, 20(4), 1-6. https://doi.org/10.1002/pa.2290

54. Wang, F., \& Xu, Y. (2004). What determines Chinese stock returns? Financial Analysts Journal, 60(6), 65-77. https://doi.org/10.2469/faj.v60.n6.2674

55. Wooldridge, J. M. (2010). Econometric Analysis of Cross Section and Panel Data. MIT Press; 2nd Revised edition.

56. World Health Organization. (2021, June 1). WHO COVID-19 Dashboard. Retrieved June 1, 2021, from covid19.who.int website: https://covid19.who.int/

57. Zeren, F., \& Hizarci, A. (2020). the Impact of Covid-19 Coronavirus on Stock Markets: Evidence From Selected Countries. Muhasebe ve Finans incelemeleri Dergisi, 1, 78-84. https://doi.org/10.32951/mufider.706159

58. Zhang, D., Hu, M., \& Ji, Q. (2020). Financial markets under the global pandemic of COVID-19. Finance Research Letters, 36(March), 101528. https://doi.org/10.1016/j.frl.2020.101528

\section{Appendices}

Apendix1 Industry-wise number of firms in DS30 (As of March 15, 2021)

\begin{tabular}{lc}
\hline Industry & Number of firms \\
\hline Pharmaceuticals \& Chemicals & 5 \\
Food \& Allied & 2 \\
Engineering & 5 \\
Miscellaneous & 1 \\
Bank & 5 \\
Telecommunication & 2 \\
Cement & 2 \\
Financial Institutions & 2 \\
Fuel \& Power & 5 \\
Insurance & 1 \\
Total Number of Firms & $\mathbf{3 0}$ \\
\hline
\end{tabular}

